\title{
INVESTIGATION OF POSTGLACIAL SEDIMENT STORAGE AND TRAnSPORT IN GARnet CANYON, TEton RANGE, WYOMING
}

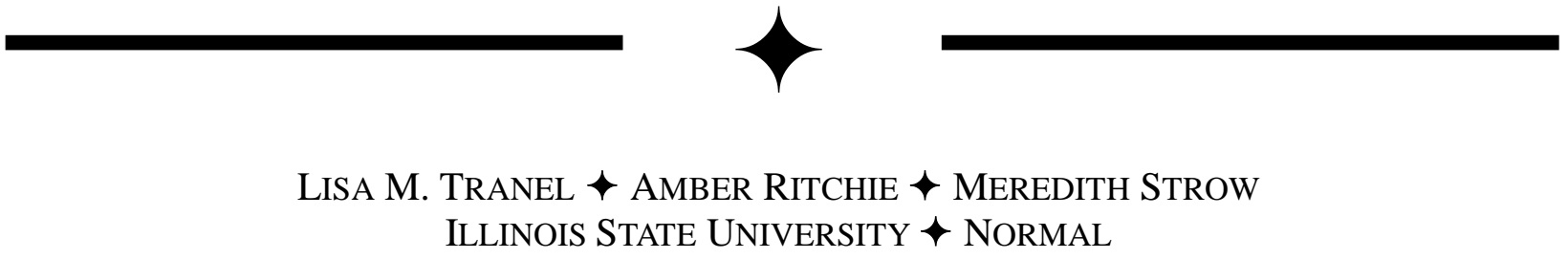

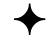

AbSTRACT

The Teton Mountains are shaped by interactions between glacial, fluvial and mass wasting processes. In this study we investigate the influence of process interactions on quantitative estimates of erosion rates based on sediment transport and accumulation. Sediment characteristics were measured on talus fan and stream channel deposits. These observations were used to evaluate weathering and rounding, which can indicate transport history and mixing between the two deposits and processes. Talus fans were studied to quantify the stability of fan surfaces and determine the frequency of material transport. Streams were studied to determine the efficiency of meltwater flow to move sand and coarser materials deposited on talus surfaces. Similarities between sediments in the fluvial and talus deposits support strong coupling between these processes. Streams are capable of moving smaller sized talus materials, however active rockfalls continue to supply new sediment and limit stream incision. The source of recent rockfalls appears to be ridges at high elevations or along north facing walls indicated by the frequency of surface weathering and lichen cover on selected talus fans.

\section{INTRODUCTION}

Rugged topography in the Teton Range was created by forces uplifting mountains relative to the Jackson Hole valley and eroding canyons and peaks by glacial, stream, and mass wasting (rockfall) processes (Love et al. 2003, Foster et al. 2010). As we investigate surficial processes controlling the landscape, we find that erosional mechanisms are closely linked. Quantifying the impact of a single geomorphic process is complicated by interactions with other processes. To understand the challenges associated with process coupling, sedimentary materials were used to measure spatial and temporal patterns of erosion in a canyon with active mass wasting and stream flow.

The accumulation of sedimentary material on a valley floor over a period of time can indicate the rate of processes creating and transporting the materials. Calculations of rockfall rates depend on estimates of the volume of rock debris collected in talus fans (Olyphant 1983), however there is uncertainty in the thickness of talus formations due to the variable debris sizes and possible transport paths on surfaces and beneath deposits. Post-depositional transport of these sediments by mountain streams may cause underestimation of the total material eroded from valley walls through rockfall events.

Sediments are transported and accumulated in stream systems and are used to measure erosion rates. Methods used to determine erosion rates and patterns include quantifying sediment transport, measuring ${ }^{10} \mathrm{Be}$ isotopes accumulated in quartz grains, and tracing minerals to source rocks (Schaller et al. 2001, Stock et al. 2006, Siame et al. 2011). The application of detrital stream sediments to understand erosion processes is dependent on how efficiently those sediments travel throughout the canyon. Stream incision can produce sediment and transform landscapes, but is limited by accumulation of sediment on canyon floors. While streams may remove talus materials, challenging the accuracy of 
rockfall erosion rates, the same talus fans may also prevent sediment transport if they create barriers to water and sediment flow (Korup 2006). Talus fans will also limit incision into bedrock on valley floors, therefore it is necessary to understand the efficiency of mountain streams to transport a range of sedimentary materials (Burbank et al. 1996, Nash 2005).

To understand erosional processes and their interactions this study focused on Garnet Canyon, where stream channels directly interact with talus deposits. Sediments on talus fans and in the stream channel were observed to measure weathering and abrasion caused by different transport mechanisms (mass wasting or stream bedload) and exposure. Rounding was measured as a possible indicator of the distance sediments traveled from the bedrock source. If sediments were deposited on the toe of the fan via rockfalls and were later incorporated into the stream channel, angularity should be similar to other clasts at the toe of the fan above or outside the channel. If cobbles were transported by water flow in the stream channel, they would be more abraded and rounded downstream. Comparisons between stream and talus sediments provide a better understanding of sediment mixing and interactions between geomorphic processes.

\section{STUDY AREA}

Garnet Canyon is a mid-sized canyon $(\sim 10$ $\mathrm{km}^{2}$ drainage area) in the center of the Teton Range (Foster et al. 2010). The canyon was eroded by several episodes of glacial advances, which created steep walls of Precambrian igneous and metamorphic rock. The slope of the valley profile decreases where glacial incision scoured and polished the valley floor. Glaciers transported eroded sediments from the canyon floor to form the Bradley Lake moraine in Jackson Hole valley (Love et al. 2003). Since the last glacial retreat, sediment has accumulated due to rockfall from adjacent, steep slopes and small stream meanders.

Based on the extent of talus deposits in Garnet Canyon, mass wasting processes are significant mechanisms of sediment formation and deposition. Rock falls and avalanches carry boulders and sediments from the steep valley walls to the floor of the canyon where the material has accumulated to form fan-shaped deposits. Rocks falling during mass wasting events are angular. Rough edges form as the boulders break into smaller sizes upon impact with the canyon wall and other rocks on the fan. Some edges may be rounded if cobbles or gravels roll from high elevations on a fan surface to the toe of the fan (Whitehouse and McSaveny 1983). Locally, large boulders and rock debris accumulated within or adjacent to the active stream channel.

Melting snow and ice from winter precipitation and a few remaining glaciers contribute to stream flow and modern sediment transport in Garnet Canyon. The morphology of the stream changes as the water flows over different bedrock surfaces or talus deposits. As the stream drains out of the northern fork of Garnet Canyon and enters the trunk valley, it creates a large waterfall cascading over glacially polished bedrock and onto accumulated glacial and talus debris. Cascades also occur where thick talus deposits accumulated along narrow reaches of the canyon. Where the slope decreases along the valley floor, step-pool morphology was observed alternating with plane-bed morphology along the channel (Montgomery and Buffington 1997).

\section{METHODS}

\section{Talus surfaces and materials}

Approximately 20 hand-sized cobbles were measured from four talus fans in, or adjacent to, Garnet Canyon. Cobbles were sampled from each fan surface to determine relative surface weathering based on lichen cover, surface color, and roundness. The four talus fans were chosen based on positions below ridges around Garnet Canyon where erosion rates were previously measured. One talus fan was sampled beneath walls facing each cardinal direction to evaluate how exposure to sunlight (warmer temperatures) influences rockfalls. The amount of daily sun exposure may influence the freezing and thawing of water in rock fractures and the frequency of rockfalls. Observations on the percentage of surface area covered by lichen provided an indication of how frequently cobbles on the fan have moved. If lichen has grown on the surfaces, it is assumed that the rocks remained in a relatively similar position for a longer period of time. The surface color provided an additional measure of surface exposure and weathering (Whitehouse and McSaveny 1983). Rocks exposed at the surface become discolored over time due to chemical weathering. We assumed that darker colors or more distinct changes in surface color indicated more weathering compared to fresh surfaces within the sample. Krumbein roundness was determined for each of the cobbles on each talus fan to measure abrasion on edges during the rockfall event. The Krumbein method assigns a quantitative 
value between $0-1$ for the angularity of sedimentary materials. The same scale was used on stream sediments to compare materials from both depositional settings.

\section{Sediment Transport}

Stream cross-sections and discharges were measured at seven sites along the stream within Garnet Canyon to determine the range of sediment sizes transported during summer discharge. The sites were selected from reaches of the catchment where the valley floor had been glacially scoured (Figure 1) and talus had accumulated. Several segments of the stream were measured to determine the sizes of sediments easily transported during snowmelt discharge. Each segment had a different morphology due to proximity of more or less recent rockfall deposition.

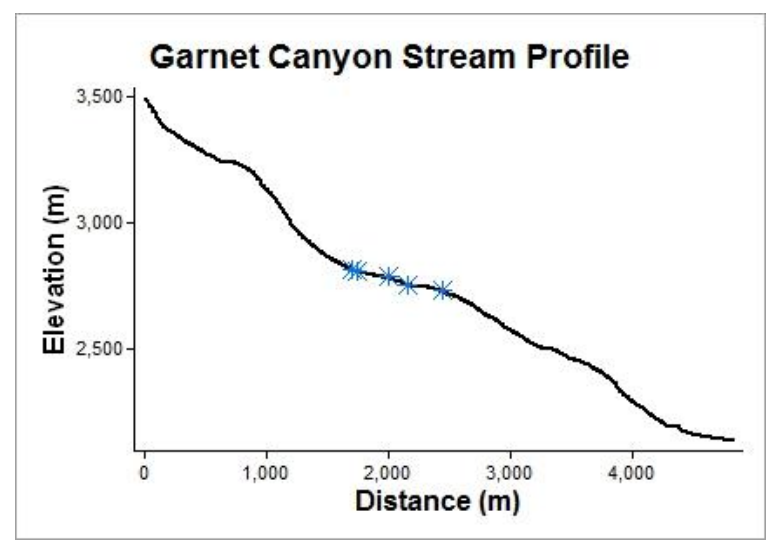

Figure 2. Longitudinal profile of Garnet Canyon begins at the lower saddle in the north fork. Blue asterisks indicate sample elevations. Samples were collected at the blue asterisks. The very steep surface directly above the asterisks indicates the waterfall from the north fork of the canyon.

Cross sections were surveyed to measure the width and depth across each channel, flow velocity, and the distribution of sediment sizes. One liter of water was also collected from one of the channel cross sections to measure suspended sediment. Surface bedload was observed in each cross section to create a grain size distribution of one hundred randomly selected grains. If a hand was placed on a large boulder that could not be moved, the boulder was measured in place. Grains that could be picked up were measured with a granulometer in the field.

Sediment sizes in the stream channel were used to calculate channel roughness, and determine a range of grain sizes transported through each stream section. Sediment entrainment was measured by calculating the boundary shear stress in the stream based on cross-section measurements. Critical shear stresses were calculated for the distribution of grain sizes observed at each stream location. If the critical shear stress was less than the boundary shear stress, grains could be transported by the discharge observed in the stream.

\section{$\downarrow \quad$ PRELIMINARY RESUltS}

\section{Talus Surfaces}

Qualitative measurements of color, lichen cover, and roundness were completed for 15-20 samples from each of the talus fans (Table 1). Samples ttc61 and ttc71 were both collected below ridges at approximately the same elevation $(\sim 3000$ $\mathrm{m})$. Sample ttc61 was collected beneath a northfacing wall and sample ttc71 was collected beneath a south-facing wall. The north-facing wall had a higher percentage of unaltered clasts $(56 \%$ original rock color) compared to the south-facing wall (29\% original rock color). Alteration of the rock changed the surface from an original light gray-white color to varieties of orange, pink or brown. The difference in color suggests talus below the south-facing wall is older, has weathered longer, and has had fewer recent rockfalls than the north facing and higher elevation walls. More lichen cover on talus sample ttc61 beneath the north facing wall also indicates lower elevation walls may be more stable than the higher elevation walls. Cooler temperatures at higher elevations may either slow weathering processes on the fan surface or enhance rockfall activity.

Table 1. Summary of talus measurements.

\begin{tabular}{|c|c|c|c|c|c|}
\hline 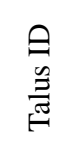 & $\dot{0} \frac{\vec{D}}{\stackrel{D}{\Xi}}$ & 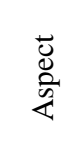 & 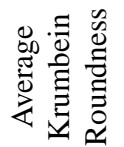 & 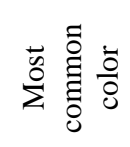 & 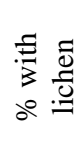 \\
\hline $\mathrm{ttc} 71$ & 15 & south & 0.3 & $\begin{array}{c}\text { moderate } \\
\text { orange } \\
\text { pink }\end{array}$ & 13 \\
\hline ttc66 & 20 & west & 0.3 & $\begin{array}{l}\text { light } \\
\text { gray }\end{array}$ & 0 \\
\hline ttc61 & 16 & north & 0.4 & $\begin{array}{l}\text { light } \\
\text { gray }\end{array}$ & 25 \\
\hline ttc64 & 20 & east & 0.4 & $\begin{array}{l}\text { very } \\
\text { light } \\
\text { gray }\end{array}$ & 10 \\
\hline
\end{tabular}

\section{Stream transport}

Measurements of stream flow and channel sediments were completed in July 2008 and repeated 
in July 2011 to determine if flow changed between the two years as a result of differences in snowfall accumulation. Average discharge calculated from velocity and cross sectional area was $\sim 1.6 \mathrm{cms}$ in both study years; therefore, the efficiency of sediment transport is similar each year. At the discharge observed, the Garnet Canyon stream is capable of transporting sand or smaller sized sediments throughout the canyon. The critical shear stress required to move sand grains $(2 \mathrm{~mm})$ was greater than the boundary shear stress (Table 2). The sizes that could be moved by snowmelt discharge ranged from fine-course gravels (pebbles-small cobbles; Figure 3 ). Talus deposits did not appear to slow velocity or limit sediment transport near any of the measured crosssections.

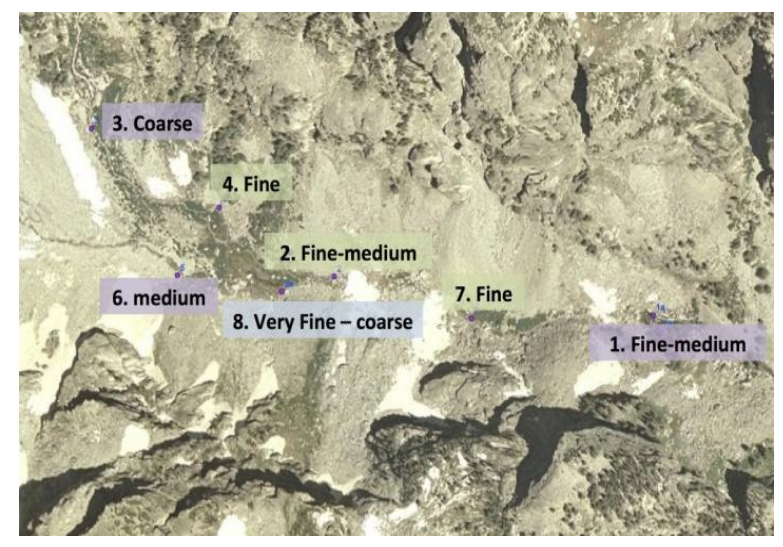

Figure 3. Stream cross section locations and the sizes of gravel that could be transported during typical snowmelt discharge.

\section{Sediment mixing between talus and streams}

Estimates of rounding on the edges of the grains were recorded for both talus and stream deposits (Tables 1 and 2). Grains were angular to subangular in all deposits. Only two talus deposits showed slightly lower Krumbein roundness values (0.3) compared to the other talus and stream sediments (0.4). The similarity between talus and stream sediments indicates that the sediments sampled were not transported far from the talus source. There was no indication that sediment in downstream deposits had traveled greater distances than sediments upstream. Rockfalls have created a transport-limited system for the streams in Garnet Canyon where the accumulation of talus material within the stream channel limits bedrock incision (Nash 2005).

Reduction of sharp edges on talus materials suggests that abrasion occurred by rolling or washing materials down the surface of the talus slopes after initial rockfall deposition. If talus materials remained unmoved after initial deposition, the edges would be very angular with little rounding on the edges. Possible post-depositional transport mechanisms include snow avalanches and rain or meltwater runoff from nearby steep slopes or gullies. As with the stream sediments, roundness of talus materials did not change with elevation or position downstream. Surface weathering can also round angular edges and indicate a relative age of talus deposits. The lack of change between high and low elevation deposits suggests this is not a good indicator of relative ages on these talus surfaces.

Table 2. Summary of stream measurements. Bolded cross sections flowed directly over talus deposits.

\begin{tabular}{|c|c|c|c|c|c|c|c|}
\hline $\begin{array}{l}\text { Cross } \\
\text { Section }\end{array}$ & $\begin{array}{l}\text { Elevation } \\
\quad(\mathbf{m})\end{array}$ & $\begin{array}{c}\text { Average } \\
\text { Krumbein } \\
\text { Roundness }\end{array}$ & $\begin{array}{l}\text { Boundary } \\
\text { Shear } \\
\text { Stress }\end{array}$ & $\begin{array}{c}\text { Critical } \\
\text { Shear Stress: } \\
\text { 2mm grains }\end{array}$ & D50 (mm) & $\begin{array}{lr}\text { Critical } & \text { Shear } \\
\text { Stress: } & \text { D50 }\end{array}$ & $\begin{array}{l}\text { Grain size moved } \\
\text { in snowmelt flow }\end{array}$ \\
\hline $1 \mathrm{a}$ & 2731 & na & 147 & 44 & 9 & 195 & fine gravel \\
\hline $1 b$ & 2731 & 0.4 & 49 & 7 & 16 & 55 & medium gravel \\
\hline 2 & 2786 & na & 74 & 15 & 29 & 208 & Fine-medium gravel \\
\hline 3 & 2871 & 0.4 & 317 & 44 & 17 & 380 & coarse gravel \\
\hline 4 & 2822 & 0.4 & 271 & 41 & 16 & 318 & fine gravel \\
\hline 6 & 2813 & na & 254 & 19 & 72 & 691 & medium gravel \\
\hline 7 & 2755 & 0.4 & 180 & 42 & 16 & 329 & fine gravel \\
\hline $8 \mathrm{a}$ & 2810 & na & 119 & 15 & 24 & 176 & coarse gravel \\
\hline $8 b$ & 2810 & 0.4 & 135 & 35 & 21 & 372 & very fine gravel \\
\hline
\end{tabular}




\section{SUMMARY}

Sediment characteristics in Garnet Canyon reflect the connections between mass wasting and fluvial processes. Mass wasting via rockfalls is a continuing process, which actively contributes sediments to the stream channel in Garnet Canyon. New sediments added to the stream channel after rockfall events limit incision, but do not strongly influence the efficiency of sediment transport. Streams flowing across talus deposits are capable of moving sediments ranging in size from sand to small cobbles, however large cobbles and boulders require higher stream discharges.

Variation in talus deposits may result from position in the canyon, ridge processes or rates of glacial retreat. Cooler temperatures below shaded or higher elevations may enhance rockfall events resulting in younger and less weathered talus deposits on the valley floor. Younger talus surfaces below the east facing wall and higher elevations may result from westerly winds carrying snow and precipitation over mountain peaks. Snow and water in rock fractures freeze and push blocks from their position in steep walls causing rockfalls to occur (Brocklehurst et al. 2011). Talus fans at lower elevations have also experienced longer exposure and accumulation time. Glacial melting and retreat slowly exposed the valley floor and allowed sediment accumulation to begin earlier at lower elevations.

\section{ACKNOWLEDGEMENTS}

Support for this project was provided by the Illinois State University New Faculty Initiative Grant. Field assistance was provided by Audrey Happel (Illinois State University) and Rebecca Rodriguez (Virginia Tech).

\section{$\downarrow$ LiTERATURE CITED}

Brocklehurst SH, Rowan AV, Plummer MA, Foster D, Schultz DM, MacGregor KR. 2011. Orographic precipitation, wind-blown snow, and landscape evolution in glaciated mountain ranges. Abstract A41D-0118 presented at 2011 Fall Meeting, AGU, San Francisco, Calif. 5-9 Dec.
Burbank DW, Leland J, Fielding E, Anderson RS, Brozovic N, Reid MR Duncan C. 1996, Bedrock incision, rock uplift and threshold hillslopes in the northwestern Himalayas. Nature. 379 505-510.

Foster D, Brocklehurst SH, Gawthorpe RL. 2010. Glacial-topographic interactions in the Teton Range, Wyoming. Journal of Geophysical Research. 115(F1):F01007.

Korup O. 2006. Rock-slope failure and the river long profile. Geology. 34(1):45-48.

Love JD, Reed JC Jr, Pierce KL. 2003. Creation of the Teton Landscape, Moose, Wyoming.:Grand Teton Natural History Association. .

Montgomery DR, Buffington JM. 1997. Channelreach morphology in mountain drainage basins. GSA Bulletin. 109(5):596-611.

Nash DB. 2005. A general method for morphologic dating of hillslopes. Geology. 33(8):693695.

Olyphant GA. 1983, Analysis of the factors controlling cliff burial by talus within Blanca Massif, Southern Colorado, U.S.A. Arctic and Alpine Research. 15(1):65-75.

Schaller M, von Blanckenburg F, Hovius N, Kubik PW. 2001. Large-scale erosion rates from in situ-produced cosmogenic nuclides in European river sediments. Earth and Planetary Science Letters. 188:441-458.

Siame LL, Angelier J, Chen RF, Godard V, Derrieux F, Bourles DL, Braucher R, Chang KJ, Chu HT, Lee JC. 2011. Erosion rates in an active orogen (NE-Taiwan): A confrontation of cosmogenic measurements with river suspended loads: Quaternary Geochronology. 6(2):246-260.

Stock GM, Ehlers TA, Farley KA. 2006. Where does sediment come from? Quantifying catchment erosion with detrital apatite (U$\mathrm{Th} / \mathrm{He}$ thermochronometry. Geology (34)9:725-728.

Whitehouse IE, McSaveney MJ. 1983. Diachronous talus surfaces in the Southern Alps, New Zealand, and their implications to talus accumulation. Alpine Research. 15:53-64. 